\title{
PENSANDO AS CRÍTICAS DE LIMA BARRETO A MACHADO DE ASSIS
}

\section{THINKING ABOUT LIMA BARRETO'S CRITICISMS OF MACHADO DE ASSIS}

\author{
Irenísia Torres de Oliveira*
}

RESUMO: Este ensaio faz uma reflexão sobre as críticas do escritor Lima Barreto ao seu antecessor Machado de Assis, procurando entender as configurações históricas, literárias e sociais que envolvem tal apreciação. Faz uma avaliação de como público e crítica da obra machadiana podem ter interferido nos julgamentos negativos do autor mais jovem e procura verificar se essa rejeição encontra motivações concretas na própria literatura machadiana. Para finalizar, propõe uma breve comparação entre dois contos dos autores.

PALAVRAS-CHAVE: Machado de Assis, Lima Barreto, crítica literária.

ABSTRACT: This article reflects on Lima Barreto's criticisms of the work of Machado de Assis, trying to understand literary, social and historical configurations that involve such appreciation. It makes an evaluation of how public and literary criticism may have interfered with the negative judgements of the junger author and it aims to verify if this rejection finds concrete motivations in Machado's own literature. To finalize, it proposes a brief comparison between two short stories of the authors.

KEY WORDS: Machado de Assis, Lima Barreto, literary criticism.

* Professora Adjunta da Universidade Federal do Ceará, Fortaleza - CE.

Email: irenisia@gmail.com. 



\section{PENSANDO AS CRÍTICAS DE LIMA BARRETO A MACHADO DE ASSIS}

As razões da implicância de Lima Barreto com Machado de Assis, explicitada pelo primeiro em conversas com amigos e em sua correspondência, parecem-me ter fundamentos interessantes que vale a pena pensar. Para além da rivalidade do escritor mais jovem com o escritor já laureado, do inadaptado com o socialmente bem-sucedido, pode haver conflitos que envolvem tanto questões de recepção e crítica no período, quanto à posição que os autores escolheram para empreender a investigação crítica da sociedade brasileira.

Em carta de 1921, Lima Barreto agradece a Austregésilo de Ataíde por "separá-lo" de Machado de Assis. Não lhe agradavam as comparações que, nesse momento, freqüentemente se faziam entre ele e o escritor consagrado. As diferenças principais, comenta na carta, estavam na secura de alma, na falta de simpatia da obra de Machado, além do seu medo de se expor e do medo do "Castilho", referindo-se à perfeita correção da prosa machadiana. Secura, falta de simpatia, reserva, linguagem correta e elevada, tudo que Lima aponta, efetivamente, são elementos de distância. Ele mesmo considera positivo chegar mais perto. A atitude contrária, portanto, afabilidade, simpatia, confissão direta e sincera, muitas vezes conflituosa e dilacerada, linguagem corrente, podem ser encontradas em sua própria obra. 
Cada um dos elementos negativos apontados pressupõe uma certa configuração de circunstâncias sociais e literárias. O objetivo desse artigo é especificar as referidas configurações e verificar, do ponto de vista crítico atual, pertinências e desvios daquelas críticas.

\section{1) 0 amor dos frívolos}

Em primeiro lugar, proponho considerar que essas reservas à obra de Machado tinham a ver com a situação da literatura no momento em que Lima Barreto atuou como escritor. Portanto, não era só uma questão de apreciação estética que estava em jogo, mas uma concepção da literatura e de sua função social. Assim, possivelmente a rejeição imediata vem da ligação que Lima Barreto estabeleceu da literatura machadiana com a literatura de seu tempo. Esta literatura, marcada pela satisfação de si mesma e pela frivolidade, constituía uma espécie de linha decadente e descendente de certas tendências de amaneiramento da literatura brasileira, que Antonio Candido atribui a uma adequação de autores a públicos. Segundo o crítico, as revistas e jornais familiares do Segundo Império tenderam a adequar os autores a um público feminino e aos serões onde se lia em voz alta.

Daí um amaneiramento bastante acentuado que pegou em muito estilo; um tom de crônica, de fácil humorismo, de pieguice, que está em Macedo, Alencar e até Machado de Assis. Poucas literaturas terão sofrido, tanto quanto a nossa, em seus melhores níveis, esta influência caseira e dengosa, que leva o escritor a prefigurar um público feminino e a ele se ajustar. (CANDIDO, 2000, p. 85).

Lima Barreto deve ter sido especialmente sensível, no sentido negativo, a essa tendência, pois julga toda a obra de Machado, numa crônica de 1919, sob esse prisma:

Machado era um homem de sala, amoroso das coisas delicadas, sem uma grande, larga e ativa visão da humanidade e da Arte. Ele gostava das coisas decentes e bem postas, da conversa da menina prendada, da garridice das moças. (BARRETO, 1956, p. 41).

John Gledson, no estudo introdutório a uma antologia de contos (1998), comenta a preferência de Machado pelas formas narrativas mais curtas e as dificuldades que teve na composição de seu segundo romance da fase 
madura, Quincas Borba. Nos contos da década de 80, entre os melhores do autor, Gledson julga que "ele pôde entregar-se ao seu amor pela anedota", já também contando com "a nova ironia que dominara". (1998, p. 38). No processo de amadurecimento de recursos, Machado parece ter buscado efetivamente o tratamento desse aspecto mais ligeiro da escrita, não sua exclusão. Para John Gledson, no conto $O$ machete, em que o violoncelista perde a mulher para um músico popular, Machado manifesta uma visão sobre o problema, expressa no desejo do protagonista de unir os dois instrumentos, o popular e o erudito, num concerto para violoncelo e machete. Na união conquistada pelo autor, o humorismo despretensioso aparece na superfície, enquanto uma nota irônica e amarga está no fundo, ou na base, da composição.

Nas Memórias Póstumas de Brás Cubas, em que estão presentes a cada passo o humorismo despretensioso e a anedota, Roberto Schwarz indica os efeitos do aproveitamento de formas mais bem aceitas pelo público, na sofisticada composição formal do primeiro romance da fase madura:

Curiosamente, o rigor sem falha com que Machado dobrou a forma do romance realista aos imperativos da volubilidade, rigor em que a parte da amargura e da descrença em face da sociedade contemporânea é grande, deu margem por sua vez ao aproveitamento de formas bonachonas e bem aceitas de espelhamento social, num espírito que não desdiz da Moreninha de Macedo ou da crônica jornalística da época, o que terá facilitado o êxito a um escritor tão estranho. (SCHWARZ, 1998, p. 49).

Se nosso escritor pôde obter êxito de público em parte porque pareceu leve e zombeteiro e incluiu formas fáceis de assimilação e espelhamento, o mesmo aspecto, considerado isoladamente, também podia passar a ser notado como defeito. No momento em que havia uma verdadeira saturação desse tipo de atitude no ambiente literário, é compreensível que Lima Barreto enxergasse em Machado a mesma disposição, já que a alternativa oferecida pela crítica também não o satisfazia, como veremos a seguir. Assim, a apreciação negativa de Lima da literatura de seu tempo, com a mania da matéria elegante e da superficialidade auto-satisfeita, deve ter refluído sobre a obra de Machado, em parte justificando a má vontade com que tendeu a vê-la.

Na má vontade de Lima, parece haver, portanto, uma motivação causada não diretamente pela leitura da obra de Machado, mas pela maneira com 
que foi lida, acolhida e interpretada pelo público e a elite intelectual em seu próprio tempo.

\section{2) A estima dos graves}

A crônica em que Lima considera Machado um escritor galante, referida acima, foi escrita onze anos após a morte do escritor. Sua motivação tinha sido o discurso proferido por Pedro Lessa na cerimônia de recepção de Alfredo Pujol na Academia Brasileira de Letras, do qual Lima destacava o elogio do orador ao extraordinário poder de abstração do inesquecível mestre, fundador da instituição. (BARRETO, 1956, p. 35) ${ }^{1}$.

Tal elogio chocava-se frontalmente com a militância de Lima no período. Já aposentado, ele começara uma intensa atuação em jornais e revistas, resenhando livros, criticando autores, como Coelho Neto, por exemplo, e discutindo um conjunto de idéias sobre literatura. O comentário sobre o discurso de Pedro Lessa apareceu, portanto, nesse contexto e marca uma tomada de posição em relação a Machado de Assis. Essa posição, para bem e para mal, baseava-se na crítica do período.

A resposta ao acadêmico vem na forma de uma discussão teórica. Lima Barreto pondera que a abstração significa na maioria das vezes uma redução ao mais elementar, não passagem ao mais complexo. "Vossa excelência quer uma espécie de arte-sinais-psíquicos, uma álgebra psicológica, separada de todas as coisas exteriores." (1956, p. 37). E percebe que a crítica, atuando dessa forma, opera uma espécie de inversão a respeito da obra de Machado: "é a sua fraqueza que o senhor Pedro Lessa quer fazer força”. (1956, p. 38).

A fraqueza, para o criador de Policarpo, era o desligamento diante de problemas, notadamente os problemas nacionais, que obsedavam os intelectuais na passagem do século XIX para o início do século XX. Lima deplorou em Machado o escritor de sala, assim como deplorava em Coelho Neto o escritor dos clubes de elite. Obviamente, ele estava errado quanto ao primeiro, mas seu equívoco me parece encaminhado não apenas por um

\footnotetext{
${ }^{1}$ Nesse discurso, transparece uma tendência crítica importante da época, idealista e cosmopolita. José Veríssimo, numa carta atenciosa, em que elogia e faz ressalvas ao Recordações do escrivão Isaías Caminha, lembra ao escritor estreante, em 1910, que arte "é, mesmo realista, idealização." (BARRETO, 1956, p. 204). Outra tendência importante, oposta à primeira e representada principalmente por Sílvio Romero, acentuava os elementos localistas como os mais importantes na obra. Machado tendeu a ser acolhido pela primeira e rejeitado pela segunda, porque as duas o interpretaram da mesma forma.
} 
erro individual de avaliação, mas pela leitura crítica dominante no período. Dialogando com esta, prefere atribuir a "leveza" machadiana menos aos humoristas ingleses, segundo ele invenção de José Veríssimo, que a Octave Feuillet, a quem Araripe Júnior atribui influência sobre os primeiros romances machadianos. (1956, p. 41-2). A tendência de Lima Barreto é acompanhar a crítica que lhe faz ressalvas, embora maciçamente tenha se estabelecido o consenso acerca do universalismo de sua obra, havendo divergências apenas quanto ao valor, ou seja, se isso seria bom ou ruim. Para o nacionalismo literário de Sílvio Romero, por exemplo, era ruim. Para a exigência militante de Lima, também.

Do ponto de vista crítico de hoje, seria impraticável considerar Machado um absenteísta. Depois dos estudos de Raymundo Faoro, John Gledson $^{2}$ e Roberto Schwarz, a obra machadiana nos aparece como constantemente interessada e atualizada com os acontecimentos históricos e políticos de sua época, além de acidamente crítica da elite e das relações sociais brasileiras. Lima não viu isso? Nem ele, nem os contemporâneos, que reputavam a Machado o mais perfeito estilo inglês e o mais elevado propósito universalizante, plasmado na descrença do ser humano "em geral", o que ao mesmo tempo é uma condenação e uma absolvição, porque se todos somos maus, se corrupta é a natureza humana, não temos por que pedir contas a alguém especificamente. $\mathrm{O}$ registro crítico, irônico, sobretudo da segunda fase, não passava despercebido, mas considerado como crítica em geral à espécie humana, podia não apenas ser aceito como usado em proveito próprio, o que talvez explique a coroação e canonização da obra machadiana, ainda hoje, pela mesma elite que representou criticamente.

No entanto, quando Lima fala em secura, falta de simpatia, omissão, distância enfim, podemos entrever momentos de uma leitura mais particular sua, de um mal-estar não inteiramente definido em relação à obra machadiana, que nem a opinião do público nem da crítica conseguiam exprimir.

\footnotetext{
2 "Afirmou um domínio, em parte baseado na indefinição, 'nesse movimento do canto da boca' que lhe confere a decisiva margem de liberdade que para nós, dadas as restrições com as quais trabalhava, parece milagrosa. Contudo, justamente porque tende a evitar distinções e a procurar a ambigüidade, isso não quer dizer que as grandes questões da época não o afetassem.” (GLEDSON, 1998, p. 36).
} 


\section{3) A sátira machadiana: dificuldade de reconhecimento}

No livro Machado de Assis: um mestre na periferia do capitalismo, de Roberto Schwarz, sobre as Memórias Póstumas de Brás Cubas, o ponto de partida é o reconhecimento de que a posição narrativa, ou seja, o eu da narrativa, é parte interessada na história, mesmo que diga o contrário. A matriz prática do desenvolto Brás Cubas é o proto-homem de classe dominante brasileira, que assume esse lugar para fazer sua própria auto-acusação. Por um procedimento literário inovador, difícil de reconhecer à primeira vista, o narrador recebia a palavra para se deixar flagrar em pleno exercício do capricho, da volubilidade, que constituía um modo de ser da elite brasileira ao mesmo tempo liberal e escravista (SCHWARZ, 1998). Sem dar a mesma ênfase à particularização social, John Gledson avalia de forma semelhante os procedimentos narrativos dos contos publicados a partir de Papéis avulsos, onde o "tom fingidamente desprendido do narrador" pactua "com seus personagens para melhor satirizá-los" (GLEDSON, 1998, p. 40).

A sátira machadiana internaliza o ponto de vista, assume os valores do satirizado, essa constitui ao mesmo tempo sua novidade e sua dificuldade. Para Hegel, a sátira seria um gênero da decadência porque dissolve a unidade indispensável à arte, entre espírito e realidade, interno e externo. A subjetividade virtuosa e abstrata coloca-se fora do mundo e o representa a partir de uma ruptura, expressa no fundamento moralista: eu sou bom, o mundo é ruim (HEGEL, 1989, p. 559-560). A fórmula satírica de Machado seria antes: o mundo é ruim, eu sou pior. Com isso, o narrador pode integrar-se à dinâmica interna, à objetividade narrativa, que resiste à determinação subjetiva externa e abstrata. No caso das Memórias, o recurso satírico é usado de maneira complexa, porque a objetividade a que tudo se submete é a do capricho de Brás Cubas. O capricho, por sua vez, sendo subjetivo, está ancorado em condições objetivas que lhe garantem o privilégio. Machado consegue, portanto, equacionar favoravelmente o problema daquela ruptura assinalada por Hegel.

Na Teoria do medalhão, que possui muitas afinidades com as Memórias, a sátira do charlatão assume igualmente o ponto de vista interno. Não se percebe a presença de um narrador propriamente condenando seu personagem, se apartando dele. Seguindo a análise de Roberto Schwarz, a narração assim assumida reveste-se de uma outra forma, histórica 
e social, uma desfaçatez de classe ${ }^{3}$. A elite brasileira do século XIX, ao mesmo tempo liberal e escravista, pode não apenas usar de uma série de artifícios para manter seus privilégios como ainda reuni-los numa espécie de filosofia de vida, dispensando-se até da hipocrisia. Brás Cubas troca desde o início a hipocrisia pela desfaçatez, a pretexto de ser um defunto autor, ainda que outros narradores de Machado, muito bem vivos, possuam a mesma prerrogativa. Além disso, podemos também nos perguntar se o narrador já morto não seria uma sátira à mania metafísica da época, também encontrada, por exemplo, na proposta desabusada de tratar a questão da alma, no conto $O$ espelho.

$\mathrm{O}$ pacto com quem se pretende satirizar, à parte ser uma solução literária, constitui uma situação de risco para o escritor. Na imagem usada por Gledson, referindo-se ao radicalismo formal e crítico da segunda fase, Machado havia dado um salto mortal, até hoje surpreendente. (GLEDSON, 1998, p. 26). O salto mortal é referido no sentido de que a crítica machadiana torna-se mais contundente. Entretanto, os elementos de superfície, incluindo a linguagem elegante, os ditos espirituosos, também se aprimoram, criando uma ambigüidade que apara o choque.

A internalização do ponto de vista é um risco, sobretudo, na possibilidade de indiferenciação dos valores da narrativa, eventualmente críticos, e os dos narradores, que podem ser especiosos. A obra de Franz Kafka, grande autor moderno que também trabalhou uma espécie de sátira com ponto de vista interno, não por acaso foi considerada muitas vezes como conformista. Narrando do ponto de vista da subjetividade constrangida e alienada, sua obra parecia querer dizer, às vezes, que o mundo não tinha saída. Inclusive, o título de uma de suas narrativas curtas é Desista!. Por que deveríamos ver através desse ponto de vista degradado? Por que Machado de Assis nos fez conhecer uma história através do ponto de vista do marido ciumento? Nos dois casos, parece haver a exigência de um leitor mais ativo, capaz de se distanciar do enredo dos narradores. No caso brasileiro, não se pode descartar o motivo do realismo. Não são as capitus, mas os bentinhos que contam as histórias.

Assim, a mudança de tratamento do narrador (verdadeiro salto mortal) redefine o papel do leitor, impondo-lhe exigências maiores. Como se diz no

\footnotetext{
${ }^{3}$ Uma desfaçatez de classe é justamente o título do primeiro capítulo do livro Um mestre na periferia do capitalismo, de Roberto Schwarz (1998).
} 
conto A chinela turca: "o melhor drama está no espectador e não no palco." (ASSIS, 2006, p. 303). Machado soube tirar efeitos extraordinários do jogo entre essas posições. A força do conto $O$ caso da vara, por exemplo, está em grande parte na posição em que o narrador coloca o leitor. Na história, o foco centra em Damião, o rapazinho obrigado pelo pai a se internar no seminário, nos levando a torcer pelo desenlace satisfatório da situação de opressão patriarcal. O pai, sem nunca aparecer, é um terror. Quando estamos bem convictos de nossa simpatia pelo rapaz, em nome dos melhores valores da civilização, somos obrigados a acompanhá-lo, agora como pactário da surra de vara que sinhá Rita dá na negrinha doente, Lucrécia. Damião entrega a vara, em troca da proteção junto ao pai. Fica muito claro que a composição narrativa quis apanhar o leitor desprevenido, colocar em xeque as boas intenções que partilhava com o rapaz. No final, o leitor descobre que a história contada era outra, para a qual não dera atenção, guiado que estava pelo narrador, mais próximo de Damião. Este conto tem a vantagem de explicitar um procedimento que, em geral, tende a ser muito sutil, sem o desfecho que ajusta as posições. Regina Zilberman, em ensaio sobre este conto, pergunta-se por que o autor teria sido tão explícito, ao ponto de carregar em alguns elementos de caracterização (Lucrécia além de tudo é doente), chegando à conclusão de que o narrador de Machado realmente teve a intenção de ser mais contundente, "engrossar a voz", assumir uma posição política, diante do público de Damiões e Sinhás Ritas da época. (1989, p. 23). Realmente, o narrador que vem acompanhando e nos faz acreditar que está contando a história de Damião, dá uma guinada no fim em favor de Lucrécia. Mesmo assim, numa situação mais explícita, Machado trata de não deixar o leitor numa posição cômoda. A crítica é também comprometimento.

Em geral, entretanto, o narrador machadiano atuou sem inflexões fortes, dificultando o reconhecimento dos valores em jogo. Uma série de fatores ideológicos, fatores externos, reforçaram essa dificuldade. De qualquer forma, como pretendemos mostrar, não foi à toa que Lima Barreto não percebeu as intenções críticas de Machado e nunca viu nele um aliado.

\section{4) Acordo ideológico}

Na linha das argumentações de Roberto Schwarz, a obra machadiana da segunda fase estabelece uma cisão entre a intenção crítica da fatura e a intenção especiosa da quase totalidade de seus narradores. John 
Gledson reforça menos a posição de classe, atribuindo a coexistência de despreocupação e amargura à conquista de um poderoso recurso de representação, a ironia machadiana. Entretanto, percebe que esse recurso intensifica a parte da amargura, quando o pobre entra em cena. (1989, p. 26-27).

Para distinguir esses vários níveis, principalmente no que diz respeito ao resultado crítico da obra, é preciso que o leitor possa ter a chance de, a partir da própria obra, construir outra forma de vê-la. Ou seja, é preciso que a obra nos dê elementos para separá-la de seu narrador.

Em princípio, não é fácil, porque o caminho da leitura e da história é criado pelo narrador, uma posição tradicionalmente respeitável, e que se apresenta, no caso da obra machadiana, de maneira sedutora e elegante. A possibilidade de ler sem seguir o narrador exige independência. Tanto que no final das Memórias nos vemos tentados a endossar as negativas cínicas de Brás Cubas, para quem havia sido uma grande vantagem ganhar o pão sem o suor do rosto e não ter filhos, mesmo que tenhamos trabalhado a vida inteira (enquanto ele não!), e amemos nossos filhos. No narrador machadiano, há de fato um poder de sedução que não pode ser desprezado.

Mas talvez também não seja tão difícil encontrar os elementos que informem sobre esse narrador, se conseguirmos nos distanciar um pouco. Estão na própria narrativa, principalmente nas Memórias e no Dom Casmurro, os fatos que podem confirmá-los como sórdidos, mas é como se os mesmos pudessem ser desprezados, diante de outros mais importantes ${ }^{4}$. Não se trata de ocultar fatos, o que tornaria a mentira mais facilmente identificável, mas sobretudo de hierarquizá-los, sobrepondo planos, reforçando o do narrador, atuando de maneira sutil na construção da visão, da aparência, não da realidade. O segredo de Brás Cubas está alardeado por toda parte no livro de contos que Machado publicou um ano depois do romance,

\footnotetext{
${ }^{4}$ No filme Memórias Póstumas, de André Klotzel, pode-se perceber que a tentativa de ser fiel ao livro levou o cineasta a excluir do roteiro justamente as partes em que Brás Cubas se mostra mais sórdido, as de ceticismo mais amargo, como se essas partes tivessem menor peso no romance. Obviamente, essa sugestão vem do narrador, que as menciona despreocupadamente. Também haveria a possibilidade de se haver excluído essas partes por serem mais difíceis, menos agradáveis ao público. Aqui também o leitor teria seguido as instruções do narrador, ou seja, do próprio Brás Cubas, conferindo-lhe mais um momento de superioridade, entre os muitos que procura afirmar no romance. Para Roberto Schwarz, Brás Cubas está sempre em busca de uma superioridade qualquer.
} 
Papéis avulsos, marcando este também, nos contos, a fase madura do autor. O segredo de Brás é o segredo do Bonzo: "se uma cousa pode existir na opinião, sem existir na realidade, e existir na realidade sem existir na opinião, a conclusão é que das duas existências paralelas a única necessária é a da opinião, não a da realidade, que é apenas conveniente." (ASSIS, 2006, p. 325). Nesse conto, de posse do grande "achado especulativo", três aventureiros em terras bárbaras (um deles aliás nativo) conseguem enganar multidões, inventando até a propaganda. Os habitantes de Fuchéu, onde se passa o conto, mostram-se sempre crédulos.

Este narrador, para ser aceito em presença de situações que o desautorizam, necessita de um acordo de classe, um acordo ideológico que lhe apague ou irreleve certas atitudes. A ambigüidade machadiana, aceita pela crítica em geral, se evidencia, mesmo sem aprofundamento analítico, na heterogeneidade e até no conflito dos elementos oferecidos ao conhecimento do leitor. A inculpação de Capitu, por exemplo, depende mais de um acordo ideológico sobre a família e o poder do pai, do que de elementos propriamente narrativos. O narrador dá o braço, portanto, ao leitor e o compromete na história. Lima Barreto recusa esse acordo, mas como não tem os elementos para diferenciar narrador e obra, procede à recusa desta como um todo.

Mas o que houve, nesse acordo, com o teor corrosivo da sátira? Não se registram reações negativas à sátira machadiana, indivíduos ou grupos ofendidos, por exemplo. A leitura universalista da obra tirou-lhe muito da virulência, permitindo que fosse aceita em seu tempo e depois. A elite brasileira que circula pelos contos de Papéis avulsos, cientistas, bacharéis, capitalistas, militares, desembargadores, conselheiros, cônegos, e são seus protagonistas, representariam uma espécie de resumo do espírito humano. Um resumo estranho, é verdade, feito mais de anedotas que de situações significativas. Uma vez diluída a crítica por todo o gênero humano, aceito o narrador, a sátira não parece apontar, condenar e corrigir costumes, como na sátira tradicional, moralista mas incômoda, e pode ser aceita na forma de uma grande auto-complacência. Como a literatura machadiana compromete profundamente o leitor, essa auto-complacência não sai de graça, mas de fato Machado não atua de maneira incisiva, como n'O caso da vara, para indicar uma visão crítica.

Não se deve exigir de um autor que tente restringir as possibilidades de leitura, até porque interpretações podem variar muito dependendo dos interesses dos grupos e das épocas e dificilmente são passíveis de controle. 
A sutileza machadiana tinha seu sentido e sua força específicos. A reflexão sobre a perda da virulência da obra machadiana em benefício de uma autocomplacência de classe, devido à sutileza do ponto de vista internalizado, interessa à finalidade de compreender por que Lima Barreto não viu ou não entendeu a obra de seu antecessor como crítica e a rejeitou.

Outra hipótese da maneira pouco virulenta com que foi sentida a obra de Machado é que o pacto leitor/narrador/satirizado dá a perceber a crítica como vinda de um igual, o que parece torná-la incrivelmente tolerável, mesmo se eventualmente reconhecida. A sátira de Lima Barreto tendeu a ser recebida com mais hostilidade, talvez porque o autor nunca tenha sido exatamente um igual. A crítica literária foi, por muito tempo, inclusive deselegante com o autor dos Bruzundangas, chamando-o de revoltado e outras coisas. No seu caso, é preciso notar também que os satirizados eram muitas vezes pessoas reais identificáveis. O roman à clef parece ter sido a saída radical de Lima Barreto para dizer que queria falar das pessoas reais, das condições de vida presentes, e não ter sua literatura remetida diretamente ao gênero humano, como a crítica tendia a fazer na época.

\section{5) Problemas de identificação: a posição de Lima Barreto}

Nesse sentido, quando Lima acusa a literatura machadiana de falta de sinceridade e simpatia, está percebendo de fato algo constitutivo nela, embora não enxergue sua função crítica. Percebe a secura do ponto de vista dominante assumido, mas não que seria um recurso de auto-acusação.

No romance Quincas Borba, o narrador está em terceira pessoa e não participa da história, constituindo uma dificuldade a mais em relação a Brás Cubas e Bentinho, que têm posições definidas na história. Sem contar com a intimidade da confissão, este narrador gosta de dirigir-se ao leitor e de dirigir seu olhar. "Vem comigo, leitor; vamos vê-lo, meses antes, à cabeceira do Quincas Borba.” (ASSIS, 2006, p. 644). No final, ainda dá ao leitor sua última instrução: "Eia! chora os dous recentes mortos, se tens lágrimas. Se só tens riso, ri-te! É a mesma cousa." (2006, p. 806). A sugestão dirigida ao leitor parece estar no espírito daquele "incomensurável desdém dos mortos", de que se gaba Brás Cubas. A falta de simpatia de que Lima acusa Machado encontra aí um bom exemplo. O mesmo narrador, que parece dar o braço ao leitor, e o guia através da desgraça de Rubião, não parece se compadecer nem nesse momento extremo. Pelo contrário, até o fim corre a pena da galhofa. A cena farsesca da morte, a dúvida final lançada sobre 
se o título do livro refere-se ao cachorro ou ao homem ("questão prenhe de questões que nos levariam longe..."), o fecho retórico que remete o olhar do leitor ao Cruzeiro e o desvia dos "risos e lágrimas dos homens", três últimos momentos que o narrador ainda aproveita para os seus "ditos espirituosos", são de um mau gosto extremo.

Se este narrador não tem uma função específica, se pode ser identificado com a figura "neutra" do próprio autor, então Lima Barreto tem toda a razão quanto a Machado: secura de alma, falta de simpatia, indiferença, frivolidade. E tem toda a razão, do seu ponto de vista, de não querer ser comparado com ele. Se lembrarmos dos tipos que Lima combateu a vida inteira, podemos talvez entender por que o narrador, e por extensão, a obra machadiana lhe inspiraram uma aversão quase intuitiva ${ }^{5}$. Enquanto a visão da obra de Machado não dá também um salto mortal, a identificação não pode acontecer sem um profundo mal-estar, pelo menos do ângulo de Lima Barreto.

\section{6) A sedução da linguagem}

Além do encaminhamento de público e crítica e da dificuldade de reconhecimento do teor socialmente crítico da obra machadiana, a má vontade de Lima Barreto pode ser atribuída a elementos daquela obra que conservam um certo teor problemático, mesmo depois da viravolta crítica empreendida nas últimas décadas, principalmente por Roberto Schwarz. O índice mais material desse problema é a linguagem. A solução formal de Machado, que lhe rende, segundo Antonio Candido, a atribuição de comprovar o funcionamento do sistema literário já formado, inclui a assunção do ponto de vista dominante. No caso dos romances, é fácil perceber porque a narrativa passa às mãos de dois representantes da elite, Brás Cubas e Bentinho. Nos contos, a linguagem se torna muito mais solene e elevada, mesmo quando trata de lições de canalhice, como no caso da Teoria do Medalhão.

Esta linguagem é o penhor do narrador elegante, educado na cultura erudita e nas finezas do comportamento em sociedade, à custa das quais conquista a identificação, quando não a simpatia dos leitores. Numa sociedade

\footnotetext{
5 "Mais de uma vez, em encontros de porta de livraria ou em conversas de café, Lima Barreto manifestou o seu desapreço à obra de Machado de Assis. Há mais de um depoimento a respeito." (BARBOSA, 1988, p. 199) Entretanto, não se devia a que ele não visse valor nessa obra: "Não lhe negando os méritos de grande escritor, sempre achei no Machado muita secura de alma, muita falta de simpatia, falta de entusiasmos generosos, uma porção de sestros pueris. Jamais o imitei e jamais me inspirou.” (BARRETO, 1956, p. 256).
} 
tradicionalmente desigual como a nossa, a qualidade de "falar bem" produz uma trajetória forte e quase autônoma, como forma de distinção.

Machado ao mesmo tempo satirizou e elevou a linguagem literária (tradicionalmente de elite) ao mais alto patamar. Por mais que sua obra seja socialmente ácida e reveladora, além de original, ela traz um veneno (uma poesia envenenada, para falar com Roberto Schwarz), porque as diferenças sociais no Brasil foram repostas a cada surto modernizador, com a sua carga de fetiches e superstições. Günter Anders, crítico alemão de Kafka, afirma que a noção de beleza que herdamos está fundada no fato da distância social, vinda de épocas fortemente hierarquizadas. “... 'belo’ é o rei intocável ou a mulher inalcançável - o que não quer dizer, eventualmente que seriam intocáveis porque são belos, antes que são 'belos’ porque intocáveis.” (1993, p. 69). Por isso, para Anders, vale como bela, em todas as culturas, primeiro a linguagem forense ou sacerdotal, porque a autoridade fornece a distância necessária à beleza. (1993, p.70).

A reflexão de Anders pode ajudar a entender em que sentido, ao mesmo tempo literário e social, a busca de Lima Barreto de se separar de Machado tinha talvez motivos pertinentes. Por mais que a obra machadiana seja um instrumento poderoso de crítica, tenha satirizado sem pena os tipos de elite, ainda são eles os portadores da linguagem bela, da maestria verbal e, com isso, ainda se impõem. A linguagem pode até dizer o sórdido, mas continua inatingível, portanto bela. Por isso, não se pôde dar mais um passo além de Machado sem questionar o próprio conceito de beleza, como fez Lima Barreto e os modernistas. A decadência que se seguiu à sua obra é compreensível. Ela mostra, quase como um efeito colateral, que a língua elevada impõe-se sobre o conteúdo abjeto e uma vez que conseguiu essa liberação, deseja agora rodopiar sozinha, sorrindo para a sociedade. Para renovar a literatura, era necessário conquistar o direito e a forma de dizer alguma coisa novamente.

\section{7) A responsabilidade do indivíduo}

A falta de simpatia de que Lima acusa Machado também tem, acredito, mais uma face. As histórias machadianas têm uma maneira particular de não gostar de suas personagens, para além do fato de que deseja satirizálas. Lima Barreto satiriza sem piedade Policarpo Quaresma, no entanto é possível notar que o aprecia. A sátira machadiana, entretanto, não apenas não gosta de suas personagens, quanto não lhes fornece atenuantes para 
as ações. No romance realista, a trama psicológica e social nos coloca duramente diante das misérias, mas explica, relativiza e com isso desonera um pouco o indivíduo. No romance machadiano, não há essa desoneração, pelo contrário. Por mais que a situação explique as ações, por mais complexa que seja essa explicação, o indivíduo sai responsabilizado. E seus atos não são inócuos, geralmente fazem mal a alguém, auferem vantagens à custa de outras pessoas.

No romance Madame Bovary, de Gustave Flaubert, o volúvel e inconseqüente Rodolphe, que conduz Emma ao primeiro adultério, sai menos responsabilizado na história porque a narrativa nos mostra que cedo ou tarde ela se entregaria a um amante. A relação de Brás Cubas, por exemplo, com Eugênia, os trocadilhos e brincadeiras de mau gosto com a moça coxa, a volta ao Rio posando de bom filho, mais tarde o encontro com ela em condições miseráveis, joga uma espécie de sordidez sobre Brás, que está longe de se assemelhar ao erro circunstanciado de Rodolphe.

Pode até explicar essa dureza o argumento do pessimismo, da descrença no ser humano. Mas pode também ser uma escolha, uma especialidade de Machado, que consiste em usar as circunstâncias não para mitigar a atuação do indivíduo, mas para mostrá-la injustificável. N'O caso da vara, o contexto narrativo explica a atitude de Damião, sem lhe tirar em nada o peso. Isso porque o alvo não é o indivíduo qualquer, como veremos adiante.

\section{8) Uma imensa loteria}

Algumas dessas questões podem ficar mais claras se compararmos dois contos, dos autores em foco: Teoria do medalhão, de Machado de Assis, e $O$ homem que sabia javanês, de Lima Barreto ${ }^{6}$. Ambas são histórias contadas do ponto de vista dos protagonistas e os satirizam.

A Teoria do medalhão se apresenta como um diálogo, um dos muitos gêneros praticados por Machado no livro de contos Papéis avulsos. Não há narrador, nem história a contar. $\mathrm{O}$ pai chama o filho para uma conversa a sós, em casa, já um pouco tarde da noite, depois de um jantar comemorativo pela maioridade do rapaz, a fim de lhe dar conselhos. "Não

\footnotetext{
${ }^{6}$ Estes dois contos foram comparados no livro Machado e Lima: da ironia à sátira, de Álvaro Marins (2004), que teve como base sua tese de doutorado defendida na UFRJ. A finalidade ali era mostrar como os dois autores tinham afinidades e poderiam ser avaliados segundo critérios muito semelhantes. De certa maneira, o objetivo aqui é inverso: chamar a atenção para diferenças significativas.
} 
te ponhas com denguices, e falemos como dous amigos sérios”. A situação tem um quê ao mesmo tempo de íntima e solene, pois marca a entrada do filho na maioridade e a preocupação do pai de encaminhá-lo, no que se assemelha a uma espécie de rito de iniciação. $\mathrm{O}$ inesperado e cômico é que o pai, depois de fazer um balanço rápido das posses e expectativas do filho para o futuro, começa a lhe dar lições de charlatanice, sem perder a gravidade.

O conto $O$ homem que sabia javanês, de Lima Barreto, também é um diálogo, mas nele Castelo conta a história das "partidas que havia pregado às convicções e respeitabilidades, para poder viver”. Aqui se trata de uma conversa muito descontraída entre dois amigos, Castelo e Castro, enquanto bebem cerveja em uma confeitaria. A história trata, portanto, de como efetivamente Castelo tornou-se um medalhão, por meio da charlatanice.

As semelhanças existem e quase podemos desconfiar da afirmação de Lima de que Machado nunca o inspirou. Mas também há diferenças significativas. A primeira história, ou seja, a história da conversa, acontece no seio da família, numa situação quase solene, de passagem de uma espécie de sabedoria de pai para filho. São gente de bem, como se poderia dizer, com diploma e apólices. No conto de Lima, a situação da conversa está fora da família, na rua, e o narrador, Castelo, conta as tais partidas para se gabar diante do amigo.

No primeiro caso, o ofício de medalhão é uma garantia, um tipo de previdência. No segundo, a malandragem consiste nos pequenos golpes que Castelo vai aplicando, em Manaus, no Rio etc., "para poder viver". É bem verdade que depois de beneficiado pelo sistema das "convicções e respeitabilidades", estabelece-se com distinção na sociedade.

A teoria do medalhão, como o nome indica, converte a malandragem em sistema, endossado pela sagrada sabedoria paterna. Não é apenas uma prática irrefletida, mas uma experiência que pode ser guiada pela reflexão e o cálculo. Nos contos de Papéis avulsos, a mesma lição aparece ainda com o prestígio de revelação esotérica, n'O segredo do bonzo, elucubração metafísica, n'O espelho, ou tirada de gênio, n'O anel de polícrates. No conto do javanês, a malandragem se apresenta como a experiência individual do bacharel pobre, Castelo, que vive de expedientes.

Nas situações apresentadas, como se percebe, não há mesmo muito lugar para simpatia, mas de alguma forma Castelo tem mais justificativa nas malandragens e espertezas, por ser pobre, não ter o que comer, nem como 
pagar o aluguel. A malandragem de alta classe tem alguma coisa de gratuita. Não se apresenta como necessidade, mas como prerrogativa.

Apesar da história de Castelo não ter a fundamentação de uma teoria e sim de uma experiência individual, torna-se muito mais evidente aqui a idéia de sistema. Castelo quase não faz nada, para atingir as culminâncias a que chega, além de aprender o alfabeto javanês. Desde o cobrador de aluguéis até o ministro, há um consenso tácito sobre a distinção de um tipo de saber, assim como no romance Recordações do escrivão Isaías Caminha, estabelece-se consenso geral, mas negativo, quanto às expectativas do estudante mulato, vindo do interior. Castelo é guindado quase contra a vontade, em alguns momentos, tendo que atenuar rapidamente alguma resistência moral ou a insegurança. $\mathrm{O}$ sistema de distinções funciona praticamente sozinho, devendo-se atentar somente para o papel fundamental que a proteção tem nele. Castelo vive de golpe em golpe até encontrar um protetor que o insira no sistema. Como diz o pai, no conto de Machado, "a vida, Janjão, é uma enorme loteria”.

A responsabilidade individual de Castelo, portanto, é muito pequena, consistindo mais na disponibilidade de aceitar o jogo. A responsabilidade maior, no caso, recai sobre o uso particularista dos sistemas administrativos e burocráticos e o sistema social de distinções. Uma enorme loteria, de fato, para o homem pobre.

No conto de Machado, a canalhice do pai e do filho é mais visível, porque a adesão ao sistema de iniqüidades é calculada e consciente: "os prêmios são poucos, os malogrados inúmeros, e com os suspiros de uma geração é que se amassam as esperanças de outra. Isto é a vida;" Como se percebe, é a versão paterna do filosófico "Ao vencedor as batatas". O pai, de certa maneira, prepara o filho para ir na onda, aproveitar-se da desigualdade da vida, tomada como fatal e inevitável, e de suas boas chances, para ganhar. No conto de Machado, ao que parece, a acusação dirige-se mais a esse assentimento familiar, íntimo, com ares de sabedoria de vida, da desigualdade que privilegia os próprios filhos. De saída, Janjão tem diploma e apólices, além da proteção do pai e "não há planger, nem imprecar, mas aceitar as cousas integralmente". No romance Quincas Borba, Rubião só entende o significado da filosofia de seu protetor, o lema das batatas, quando herda todos os seus bens e fica rico. Depois, porque não tinha experiência de vencedor (faltaram-lhe talvez as instruções de um pai), acaba perdendo tudo, enlouquecendo e morrendo. 
A preferência de representação para Lima Barreto recaiu, principalmente, nos pobres. Considerava que precisávamos nos atualizar nesse sentido, em relação à Europa. Também viveu na época em que o movimento operário começou a se organizar e as classes médias pretenderam ter alguma influência na vida pública. A representação da experiência, do grau de comprometimento desses contingentes sociais nos problemas do país, desafiava o escritor.

Podemos notar que, no final do conto de Lima, Castelo é cônsul, mas no início vive ao deus dará e é praticamente corrompido ao ser beneficiado pela burocracia da República, dirigida por barões e viscondes. O personagem, mesmo se acanalhando na história, não deixa de atrair a simpatia pelo indivíduo astucioso que engana os poderosos, assemelhando-se ao Pedro Malazartes da literatura popular. Além disso, Castelo não faz mal a ninguém. Encontra um protetor como quem ganha na loteria.

O álibi da malandragem dos personagens de Machado é a desigualdade (poucos prêmios, inúmeros malogros). Obviamente é uma justificativa especiosa que toma o dado como certo, quando é apenas conveniente. Isso está dito, com todas as letras, na doutrina do bonzo, já referida neste artigo: “... das duas existências paralelas a única necessária é a da opinião, não a da realidade, que é apenas conveniente." (2006, p. 325).

A personagem preferida de Machado, na segunda fase, parece ter sido esse indivíduo com prerrogativas. As circunstâncias dão conta dos privilégios, muitas vezes o privilégio de contar a história, que pesam sobre suas ações.

Nesse sentido, a falta de simpatia que Lima viu em Machado como defeito era parte de um instrumento crítico radical, o sinal de insubordinação que Lima tanto cobrou do antecessor, sem reconhecê-lo.

\section{Referências Bibliográficas}

ASSIS, Machado de. Obra completa. Rio de Janeiro: Nova Aguilar, 2006, v. 1 e 2 .

BARRETO, Lima. Contos reunidos. Rio de Janeiro/Belo Horizonte: Garnier, 1990.

. Correspondência. São Paulo: Brasiliense, 1956, 2 v.

Feiras e Mafuás. São Paulo: Brasiliense, 1956.

BARBOSA, Francisco de Assis. A vida de Lima Barreto. 7a. ed. Belo Horizonte: Itatiaia; São Paulo: Editora da Universidade de São Paulo, 1988. 
CANDIDO, Antonio. O escritor e o público. In: Literatura e sociedade: estudos de teoria e história literária. $8^{\mathrm{a}}$. ed. São Paulo: T. A. Queiroz, 2000, p. 73-88.

GLEDSON, John. Os contos de Machado de Assis: O machete e o violoncelo. In: ASSIS, Machado. Contos: uma antologia. São Paulo: Companhia das Letras, 1998, 2v, p. 15-55.

HEGEL, G. W. F. Ästhetik. I/II. Stuttgart: Reclam, 1989.

MARINS, Álvaro. Machado e Lima: da ironia à sátira. Rio de Janeiro: Utópos, 2004.

SCHWARZ, Roberto. Um mestre na periferia do capitalismo: Machado de Assis. 3a. ed. São Paulo: Duas Cidades, 1998.

ZILBERMAN, Regina. Um caso para o leitor pensar. In: Revista de Letras, v. 29, São Paulo, 1989, p. 19-24.

Recebido em 25 de novembro de 2007

Aceito em 26 de fevereiro de 2008 